\title{
Creating an Inclusive and Multicultural Classroom by Differentiated Instruction
}

\author{
Suleyman CELIK, PhD \\ Tishk International University \\ Erbil/Iraq
}

\begin{abstract}
There is no doubt that today's learners vary in many ways such as in their experience, socio-economic status, culture, ethnicity, learning styles, as well as in cognitive areas. These diverse learners bring their own learning and personal character to the classroom, which in turn influence factors including classroom atmosphere and time management, content to be taught, and teaching methods. In order to meet learners' needs and in order to improve their strengths, different types of instructional methods ought to be applied such that the natural diversity prevailing in the classroom does not prevent any learner from achieving the instructional goals, in other words to engage all the learners to the learning environment. Adapting different instructional methods to different learners allows the teacher to build an inclusive classroom environment. One approach to building an inclusive classroom is differentiated instruction. Within this perspective, action research was conducted with fifth grade learners in a private primary school, Erbil, Iraq, in order to determine how differentiated instruction built an inclusive environment in the classroom.The results of the research were significant and showed that when students are provided differentiated instruction that meets their needs, a tipping point can be reached. Moreover, inclusive education always helps the teacher to establish a positive learning environment.
\end{abstract}

Keywords: differentiated instruction; diversity; inclusive classroom; inclusive education

\section{Introduction}

It is known that teaching concerns not simply the transmission of knowledge from the sources of knowledge to learners through teachers, but rather it is the interaction of teachers with learners. However, there are challenges and contradictions in today's classrooms with regards to the teaching and learning process. For example, some learners gain poor grades, and others good grades, even when the teacher is skilled at transmitting the content of the day's lesson. In addition, some learners want to learn, whereas others do not even want to come to school; some learners want to do extra work, and others do little at all; some learners are actively engaged in the learning process; while others are not. These typical challenges occur because of the individual differences that exist in every classroom, and which absolutely influence the outcomes of the teaching, regardless of how adept a teacher may be at transmitting the contents of the day's lesson.

If it is thought necessary to create positive and inclusive classrooms in the education field, the teachers ought to be aware of the diversity of the learners. According to Groundwater-Smith (2009), diversity refers to "...the range of differences that encompass such cultural factors as ethnicity, language, ability and special needs" (p.54). However, there are also many more factors are involved as well. It is not easy to say that learners fall into only one category or another, and may demonstrate characteristics from several categories (Tomlinson, 2014). The learners vary in different ways, such as in cognitive, affective and physical areas; when it comes to differences of gender, ethnicity, learning style, language, or creative potential; differences resulting from exceptionalities, and at-risk characteristics; and others. Thus, an effective teacher ought to be aware of all these factors so as to ensure that they are trying to be as inclusive as possible in the classroom. The awareness of learner diversity immediately presupposes an awareness of the way in which each learner learns. As not all the learners are alike, their learning preferences also differ (Tomlinson, 1999; Tomlinson, 2003). This diversity ought to be taken into consideration when trying to engage those learners in the lesson, which proves itself to be one of the most challenging aspects of teaching. This diversity also can be a positive resource in the classroom, and something to be embraced, which indeed proves very important (Davies, 2006). Having all the different students participate in the classroom activities makes the classroom an inclusive learning atmosphere where all learners take part in and join the lesson.

An inclusive education is described (Allen \& Cowdery, 2011) as a conception of education where everybody has a place, and where everyone is participating. In inclusive classrooms, everyone is constantly learning, because this constitutes a positive social learning environment where learners have a place and have roles to learn. So, in that positive community, learners acquire knowledge not only of the academic requirements and learner outcomes, but they also learn how to get along with each other (Salend, 2010). 
They also learn how to manage conflict bills, and they learn a wide variety of citizenship skills and knowledge related to learning, and how to work and live together. According to Terrell and Lindsey, (2008) one of the greatest features of inclusive education is that it brings a unique sense of learning environment to the schools and classrooms, where people think pay of attention to and be responsive to what is going on in the classroom. There is not only a strong and positive learning atmosphere in inclusive classrooms, but learners and teachers are also bound together by strong emotional ties and almost become a community and family. To build a climate like that, a variety of lesson plans, which include positive outcomes for all the learners, should be prepared.

Alexander, Johnson, Leibham and Kelley (2008) describe the term inclusive having come to refer to the inclusion of children with disabilities and regular classrooms for children without disabilities. Here, inclusive refers to the inclusion of all children with intrinsic factors and extrinsic factors, such as: socio-economic status; unsafe living environments; uninvolved parents; weak health care factors; and inexperienced or insufficient teachers (Engelbrecht, Oswald \& Forlin, 2006); being left out or excluded from school; for example children who don't speak the language of the classroom, or who belong to a different religion; and being at risk of dropping out of school due to sickness, being hungry, not achieving well, or operating at a low cognitive level. It also refers to girls who are pregnant; children affected by certain diseases; and girls and boys who be in school but are not, especially those who work elsewhere to help their families to survive.

\section{Create a supportive, Caring Environment}

According to a research conducted by Engelbrecht, et al. (2006) in South Africa, inclusive education seeks all available support from school authorities who are to bring a collaboration among the staff to build a creative environment, the community, the family, educational institutions, health services, and of course community leaders, to respond to the diverse needs of learners. The inclusion also ensures the quality education regardless of the learners with or without learning disabilities through appropriate curricula and organisational arrangements. The teachers inside the inclusive classrooms ought to use different teaching strategies, resources and partnership with their communities. In their comparative research, Nel, Muller, Hugo, Helldin, Backman, Dwyer and Skarlind (Nel et al., 2011; Nel et al., 2011) indicate that in order to implement inclusive education effectively in the classroom, the mindset of teachers have to change accordinglyand they argue that some South African teachers did not feel themselves proficient enough to teach in such manner of classroom. One of the definitions of an inclusive school is that it is one that honors and supports all learners (Burden \& Byrd, 2007). Besides, Walton, Nel, Hugo \& Muller (2009) define the inclusive regular schoolsas a means of combating discrimination and achieving education for all in a cost-effective way. Inclusiveness is about creating a supportive community around all of our learners and fighting against the 'barriers to learning'. Inclusive education is about having an environment in which 'all learners can learn' (Engelbrecht, Nel, Nel \& Tlale, 2015) and have the opportunity to work with each other regardless of their disability, race, ethnicity, sexuality, and ability (Bennett, 2001).

\section{Celebrating diversity}

In inclusive classrooms there is no discrimination between the learners with disabilities, and those without disabilities. Each learner contributes to the rich variety of ideas and actions in the classroom. Those learners ought to be welcomed and appreciated, and it the diversity that is reflected in the classrooms ought to be valued by all. In turn, the learners will feel appreciated, which will make them feel more comfortable rather than merely feeling a sense of being different. This sense of feeling appreciated is a feature endemic to the inclusive classroom. The curriculum and the assessment of the programs are designed to meet the learners' needs and to lead those students to achieve the learning outcomes and goals of the lesson.

\section{Respond to all learners enthusiastically}

According to the study conducted by Engelbrecht, et al (2015), teachers' perspectives on and perceptions of an inclusive classroom influence students' engagement with a positive and inclusive learning environment. Anderson ( 2007) defines the teachers' job indicating that the teacher ought not to be required to determine whether a student ought to be participating, but how they should participate. When teachers are including learners, they are thinking about how they make their schools responsive to every learner that walks in the door, how they really appreciate, identify and honor the individuality and uniqueness that their learners bring, and how they provide an appropriately challenging education to all(Huang, 2002). That is because they try to align everything, they do with their vision of being truly integrated socially. All the learners have the right and deserve the chance to be in those classrooms, to be given opportunities, to show who they are and what their strengths are, and to build on those as human beings. In addition to its benefits and advantages, inclusive education has some constraints as well. First and maybe the most important emerging issue is economic and financial resources of this education model. 
This requires financial support and this support should be adequate enough to provide all the needs of the inclusive schools, classrooms, and teaching, as well as learning processes that include staff training. Developing countries in particular, such as South Africa, Kosovo, Turkey and Kyrgyz Republic, show that they have difficulty in the implementation of inclusive education, due to the financial demands implied (Nel et al., 2011). On the other hand, South and North African countries, where there is really a low-income, use the human capitals as the economy resources and they are really successful in using these recourses effectively. One of the economically suffering country is Kurdistan Region of Iraq, where saving or investing to the education is nearly not in the government's agenda. The economy of Kurdish Region of Iraq (KRI) is dependent on oil, agriculture and tourism. The GDP of the region per year was $\$ 26.5$ billion in 2015. However, the economic situation was harshly effected after the crisis in 2015 . In addition, the fall in oil prices, disagreements with the central government and the rapid expansion of ISIS hit the economy of KRI. The central government of Iraq cut the \%17 budgets of its income reserved for distribution to KRG hasn't been allocated since February 2015. Many government officials including teachers, soldiers and other employees haven't been paid since October 2015.

After the independence referendum for KRI, held on September 2017, the economy of KRI became worse and has been suffering since then. Within this fragile and very poor economy the Kurdish Administration funds Education in KRI. The KRI is having many obstacles in front of an ordinary education. The growth of the school age children, the increased number of IDP's, internal migration from rural to urban areas, the growing population and decreased economy resources putting unprecedented pressure on the schooling across the country. Moreover, there is a double shifting in the schools in order to accommodate growing pupil numbers.

Nowadays, in Kurdistan Region finding resources of funding for the education is a big problem, but the bigger problem is distribution and allocate of these limited recourses to overcome lack of schools, overloaded classrooms, lack of teachers and inefficient educational technologies. As a result of these obstacles and lack of economy resources, education in Kurdistan Region is suffering. However, inclusive education can be a solution to improve the quality of education in a suffering environment and in a long term the educational expenses will turn into beneficial investments.

So far, many frameworks have been designed in order to create an inclusive learning atmosphere for the diverse learners; as well as to help them identify their learning styles. Differentiated instruction is one of those frameworks by which the teacher constantly changes the content (the curriculum, materials and approaches used to teach the content), process (the instructional activities or approaches used to help learners to learn curriculum), and product (the assessment tools through which learners demonstrate what they have learnt), according to the learners' levels and needs.

\section{Differentiated Instruction}

However, understanding the source of diversity is not enough to teach effectively. This information ought to be used as the basis of many classroom decisions when building a positive and caring learning environment, selecting a responsive curriculum, determining instructional strategies, and providing assistance. All these factors can be combined within the differentiated instruction, where, in other words, teachers can differentiate their teaching methods when planning, grouping learners, using instructional activities and materials, identifying assignments, and determining the assessment to use(Borich, 2008). Differentiated instruction can be effective in responding to the whole class or group of learners in the same classroom, who may differ when it comes to academic success. Differentiated instruction is based on the premise that instructional approaches ought also to vary according to the individual whose academic success is or could be enhanced by a more targeted and individualized approach (Tomlinson, 2000). In order to provide differentiated instruction, the teacher ought to know their learners' learning history, background, prior knowledge, readiness to learn, interests, and acquired skilled set. Based on these differences, teachers ought to tailor their instructional strategies for a small group or an individual learner to speed up academic success, which might be slowed if only large group instruction is available. Patterson, Connolly and Ritter (2009) identify the goal of differentiated instruction so as to maximize each learner's personal growth and academic success, by meeting each learner at his or her current level to the next step on the learning ladder. Differentiated instruction is a term that is well worn in education today. Teaching is akin to bowling, where, if learners are taken as bowling pins in the analogy, the proverbial bowling ball is guided to run down the middle of the bowling lane, so as to strike the greatest number of pins at once. In general, this is a very traditional idea of what teaching ought to be. It certainly does not describe differentiation, where differentiated instruction involves the teacher not merely serving students in the middle, but requiring all of the learners, namely those in the middle, and those on both ends of the learning spectrum (Watts- Taffe, Broach,, Marinak, McDonald Connor, \& Walker- Dalhouse,2012). Tomlison (2004) demonstrates three elements of the curriculum, namely content, process and products that can be differentiated to make instruction more responsive to the individual needs of learners. According to Burden and Byrd, (2007), differentiation happens where teachers vary the content of their instruction,and involves the process that learners take, the products that are created, and finally the classroom environment. 


\begin{tabular}{|c|c|}
\hline Areas & Examples \\
\hline $\begin{array}{l}\text { Content: the knowledge, skills, and attitudes related to } \\
\text { the subject and the materials and mechanism through } \\
\text { which learning is accomplished }\end{array}$ & $\begin{array}{l}\text { - Using texts or novels at more than one reading } \\
\text { level } \\
\text { - Instructions through both whole-to-part and part- } \\
\text { to-whole } \\
\text { - Using types of educational technologies as a way } \\
\text { of conveying key concepts to varied learners } \\
\text { - Focusing on the principles and the key concepts, } \\
\text { rather than the details } \\
\text { - Provide different tasks to different level learners } \\
\text { - Use varied text and materials }\end{array}$ \\
\hline $\begin{array}{l}\text { Process: instructional activities or approaches used to } \\
\text { help learners to learn the curriculum }\end{array}$ & $\begin{array}{l}\text { - Provide options at differing levels of difficulty } \\
\text { - Provide options based on differing learners' } \\
\text { interests } \\
\text { - Vary from whole class, to collaborative groups, to } \\
\text { small groups or to individuals } \\
\text { - Provide incentives to learn based on a learner's } \\
\text { individual interests } \\
\text { - Develop different activities that seek multiple } \\
\text { perspectives on topics and issues. } \\
\text { - Tiered assignments }\end{array}$ \\
\hline $\begin{array}{l}\text { Product: are the vehicles through which learners } \\
\text { demonstrate what they have learned }\end{array}$ & $\begin{array}{l}\text { - } \text { Model respect } \\
\text { - Provide teachers a menu of choices such as oral } \\
\text { responses, interviews, demonstrations and formal } \\
\text { tests } \\
\text { - Keep each learner at his or her level } \\
\text { - Giving learners opportunities that may express } \\
\text { themselves such as writing a story, drawing a } \\
\text { picture or telling about a real-life experience }\end{array}$ \\
\hline $\begin{array}{l}\text { Learning Environment: classroom functions and } \\
\text { feeling }\end{array}$ & $\begin{array}{l}\text { - Rearrange furniture to allow for individual or } \\
\text { small group discussions } \\
\text { - Availability of supplies and materials }\end{array}$ \\
\hline
\end{tabular}

Figure 1 Overview and Key Concepts for Differentiated Instruction

Although students may not be one type of learner, presenting information in a variety of ways ensures that more learners have the opportunity to comprehend what the teacher teaches them. Teachers can change the environment by using strategies such as flexible seating, to allow learners to work where they're most comfortable. Teachers can establish a growth mindset to help learners understand learning as a series of goals to be accomplished instead of grades that they'll achieve. Learners can develop risk-taking skills, independent thinking, and collaboration skills as they co-construct their learning with the assistance of their classroom community, so as to vary the process. This begins with focusing on allowing the learners to choose how they will complete the set of criteria, by giving them options and choices, and giving them ownership in their own learning. They're not simply just receiving the instruction, but they're actively participating in the construction of their learning. Some call this approach inquiry-based learning (Applebee, Gamoran Langer \&Nystrand 2003; White, Shimoda \& Frederiksen, 1999). Differentiated learning tasks take into account the learning preferences interest and readiness of the learners. Teachers need to ensure that these features of differentiation trickle down through their teaching and learning cycles and impact their planning instruction and assessment. "Learning happens best when a learning experience pushes the learner beyond his or her independence level"'(Tomlinson C. A, 2001:8) is a wonderful quote revealing of the fact that learner's readiness is important for differentiation. Differentiated instruction must work in a given learners' zone of proximal development, and the teacher must understand where those learners are currently, where they need to go next, and what steps they will need to take. Therefore, differentiated instruction is ideally suited for a heterogeneous classroom (Brophy, 1998) in which learning histories, learning styles, learner interests, as well as skills and disabilities representing special populations may all respectively impair learning. To make frequent assessments will help the teachers to where they are and what they need, in terms of what essential beliefs teachers need to have in order to create an environment of real differentiation. Firstly, a culture of high expectations for all learners needs to be set, where there is an understanding that every learner can achieve, regardless of the barriers or challenges that they may encounter, ensuring that students are receiving the same opportunities for higher order thinking. It cannot be just gifted and talented learners that are deemed capable. This is needed so as to ensure that all learners have the opportunity to show higher order thinking skills, even though teachers need to figure out a way to allow this to happen. Within this concept of inclusive education and differentiated 
instruction, this article describes how the secondary school English Language Teacher in fifth grade used differentiated instruction to create an inclusive classroom in which all learners' needs were met. The teacher used differentiated instruction to engage diverse learners in her English courses, and the methods she used allowed her to provide opportunity to learners for their learning in a manner compatible with the given learner's own learning strengths and preferences. The curriculum was defined in terms of what a learner would be able to demonstrate (Anderson, 2007; Tomlinson, 2001, 2004).

\section{Purpose of the research}

The primary purpose of this study was to engage all those aforementioned learners as a sample and to prove that different types of teaching method can set inclusive education. First, the teacher focused on engaging all the learners in English Language classes and provided them the opportunity of reaching their peak point based on their level. By providing differentiated instruction, it was believed that the learners' needs would be met, and as a result, that they would be more motivated. Also, she aimed for the classroom management problems to be decreased at the minimum level. As a result, at the end of the action research, an inclusive classroom is to be created in which all the learners were expected to participate the courses eagerly. All 26 learners took part and the inclusive class run by their English Language teacher. Besides demonstrating a sample of an inclusive classroom, the teacher hoped to set an example that may persuade the school to become an inclusive school and a safe place in which all the students could achieve to the best of their ability.

\section{Research question}

\section{Main question}

How does differentiated instruction help the teacher to engage all the students and create an inclusive classroom where there is always a learning atmosphere?

\section{Sub-questions}

1. How does the teacher change her teaching to facilitate more meaningful participation in her English Language classroom?

2. Will including all learners into the lesson let learners to learn the content at a higher level?

3. Will creating an inclusive classroom help teachers to minimize classroom management problems?

4. Will creating an inclusive classroom help learners to internalize and apply the knowledge in the world around them?

\section{Methodology}

In this study, a mixed method research design, which combines quantitative and qualitative approaches, was conducted. The purpose of designing mixed-method research was to build on the synergy and strength that exist between qualitative and quantitative methods, in order to understand our case fully. So far, many hypotheses about inclusive classroom have emerged. To test these hypotheses in an Iraqi environment, the researcher used statistical data and administrates pre-tests and post-tests, and questionnaires, and in addition to this deductive approach, she tried to use inductive method to generalize the idea in her school. So, she interpreted the learners and their parents' interviews. She also tried to understand the relationship between cause (differentiated instruction) and effect (inclusive classroom). She additionally selected the participants purposefully based on their inefficiency in their English classroom. The researcher has confidence that she knows the learner-centered education and has tried to engage all her learners to the lessons without leaving anyone behind. She taught English as a foreign language in the fifth grade of primary school. Her classroom was a unique one in regards to diverse learners. She tried avidly to engage all her learners in order to improve the inclusiveness and develop her learners' cognitive skills. The researcher has been an English Language teacher for five years and she has faced many problems regarding learners' participation in the lesson, so as to create a positive learning environment, by providing an inclusive classroom. The researcher studied these problems to determine their root cause, and consequently to evaluate and correct her decisions by taking required actions concern her teaching and learners' learning.

Although the number of learners in that action research classroom were not excessive, the desired development of the learners was not very satisfactory. The learning outcomes of the courses were not being achieved, andconsequently, classroom management problems surfaced and numerous cases of ill-discipline were reported. There may have been many reasons for this collapse, but the reality was that the needs of students were not being met.

\section{Sample selection}

The subjects described in this article took place in an inclusion class at Private Primary School, a school serving approximately 600 learners in grades one through six. Nearly $75 \%$ of the learners at the school were Kurds, $10 \%$ were Arabs 5\% were Turkish, 5\% were Turkmens, and the others were from different ethnicities. The action research took 
place with 26 learners in a $5^{\text {th }}$ grade English Language classroom for three months, where the distribution of the learners was the same as the distribution of the school. That classroom was a prototype of the whole school. There were Kurdish, Arab, Turkmen, Turkish and Yezidi learners, whose background information, culture, SES, and cognitive area differed from those of one other.

The subjects were chosen purposefully because they were not in a high-order thinking level in English Language. They used to come to the school with a neutral mood, and usually tried to destroy the classroom learning atmosphere. When they did not disturb the class, they were either very tired or asleep, and they were not interested in the lesson. For these learners it was almost impossible to continue with the curriculum or with studying. The background knowledge of the classroom was almost the same as in the previous years, and many of them were at risk to fail in all subjects. Many of the learners were treated as "lost cause" and seemed unmotivated. Many of their parents were not involved to the education process and the learners were intrinsically demotivated, placing barriers to learning.

\section{Data Collection and Analysis}

Thedata was collected from different sources such as learner observation checklist, learner questionnaires, learner examinations, and interviews. Also, parents were asked their ideas, whether they recognize any change in their learners' learning behaviors. To analyze these data, literature through teacher journal was read and a statistical analysis of the data obtained through these tools was held.

\section{Chart 1Triangulation of Data}

\begin{tabular}{|c|c|c|c|c|c|}
\hline & \multicolumn{5}{|c|}{ Data Collection Instruments } \\
\hline Research Question & 1 & 2 & 3 & 4 & 5 \\
\hline $\begin{array}{l}\text { How differentiated instruction } \\
\text { helps the teacher to engage all } \\
\text { the learners to create an inclusive } \\
\text { classroom where there is always } \\
\text { a learning atmosphere? }\end{array}$ & $\begin{array}{l}\text { Teacher } \\
\text { Journal }\end{array}$ & $\begin{array}{l}\text { Learner } \\
\text { Observation }\end{array}$ & $\begin{array}{l}\text { Learner } \\
\text { Examinations }\end{array}$ & $\begin{array}{l}\text { Learner } \\
\text { Interviews }\end{array}$ & $\begin{array}{l}\text { Learner } \\
\text { Questionnaires }\end{array}$ \\
\hline $\begin{array}{l}\text { Will including all learners into } \\
\text { the lesson allow learners to learn } \\
\text { the content at a higher level? }\end{array}$ & $\begin{array}{l}\text { Learner } \\
\text { Observation }\end{array}$ & $\begin{array}{l}\text { Learner } \\
\text { Questionnaires }\end{array}$ & $\begin{array}{l}\text { Learner } \\
\text { Examinations }\end{array}$ & $\begin{array}{l}\text { Learner } \\
\text { Interviews }\end{array}$ & \\
\hline $\begin{array}{l}\text { Will creating an inclusive } \\
\text { classroom help teachers to } \\
\text { minimize the classroom } \\
\text { management problems }\end{array}$ & $\begin{array}{l}\text { Learners } \\
\text { Observation }\end{array}$ & & & & \\
\hline $\begin{array}{l}\text { Will creating an inclusive } \\
\text { classroom help learners to } \\
\text { internalize and apply the } \\
\text { knowledge in the world around } \\
\text { them? }\end{array}$ & $\begin{array}{l}\text { Parents } \\
\text { Interview }\end{array}$ & $\begin{array}{l}\text { Learner } \\
\text { Questionnaires }\end{array}$ & $\begin{array}{l}\text { Learner } \\
\text { Observations }\end{array}$ & $\begin{array}{l}\text { Learner } \\
\text { Interviews }\end{array}$ & \\
\hline
\end{tabular}

\section{The Journal}

While trying to find out the root causes of why the learners did not join the classes, the teacher read some of her journal entries, which could help her to make the classroom as a learning atmosphere where all the learners could participate by meeting their needs. Reading journals helped her to create an inclusive classroom by using differentiated instruction a couple of months after she started her action research.

\section{The Learner Questionnaire}

In order to identify the problem of learners not engaged to the classes and the ways of engaging them to the lessons, the teacher conducted the same questionnaires before and after the action research. The questionnaire was made up by the teacher, and tailored by the author, based on the literature review. The greatest benefit of the pre-questionnaire was that the learners allowed the teacher to know that engaging the classes can occur by group work, different ways of teaching and accessible content, as well as which were the easiest and most attractive assessments; not only with quizzes and examinations. Some of the hard-working learners preferred to study with a group and from different sources. More than half of the learners thought that differentiated instruction would be more motivating and they thought that they would 
be more secure in an inclusive classroom. Nearly all the learners complained about the ongoing teaching materials and techniques, and they indicated that they were very bored in the classroom. The post-questionnaire showed that constant changes in regards to content, process and assessment made the learners very active and more motivated. Small group work, pair works, different contents and different types of assessments gave the learners more confidence and they increased their grades. At the end of the action research period, the teacher witnessed that using differentiated instruction resulted in creating an inclusive classroom, where all the learners engage and participate at their levels.

\section{Learner Observation}

The learners' own observation served as a useful tool for examining the situation in class as the research was conducted. Generally, the observation made not only during the classroom time, but also in learners' free time as well. The teacher kept a diary to record to compare the learners' behavioral changes as the time being. After the teacher began differentiated instruction in which she used different contents, different techniques and assessment which met the learners' needs, their motivation was aroused and they were much more eager to participate in the lessons.

\section{Learner Examinations}

At the beginning of the study proficiency pre-test and post-test were administrated to measure their progress at the end of the research by conducting the same test. In order to be certain about their progress, the learners' mid-term and final exams and quizzes were taken into consideration. Those examinations enabled the teacher to see how differentiated instruction teaching activities affected the learners' progress in English Language courses. From an inspection of all those examinations of the English Language courses, there seemed to be significant differences arising.

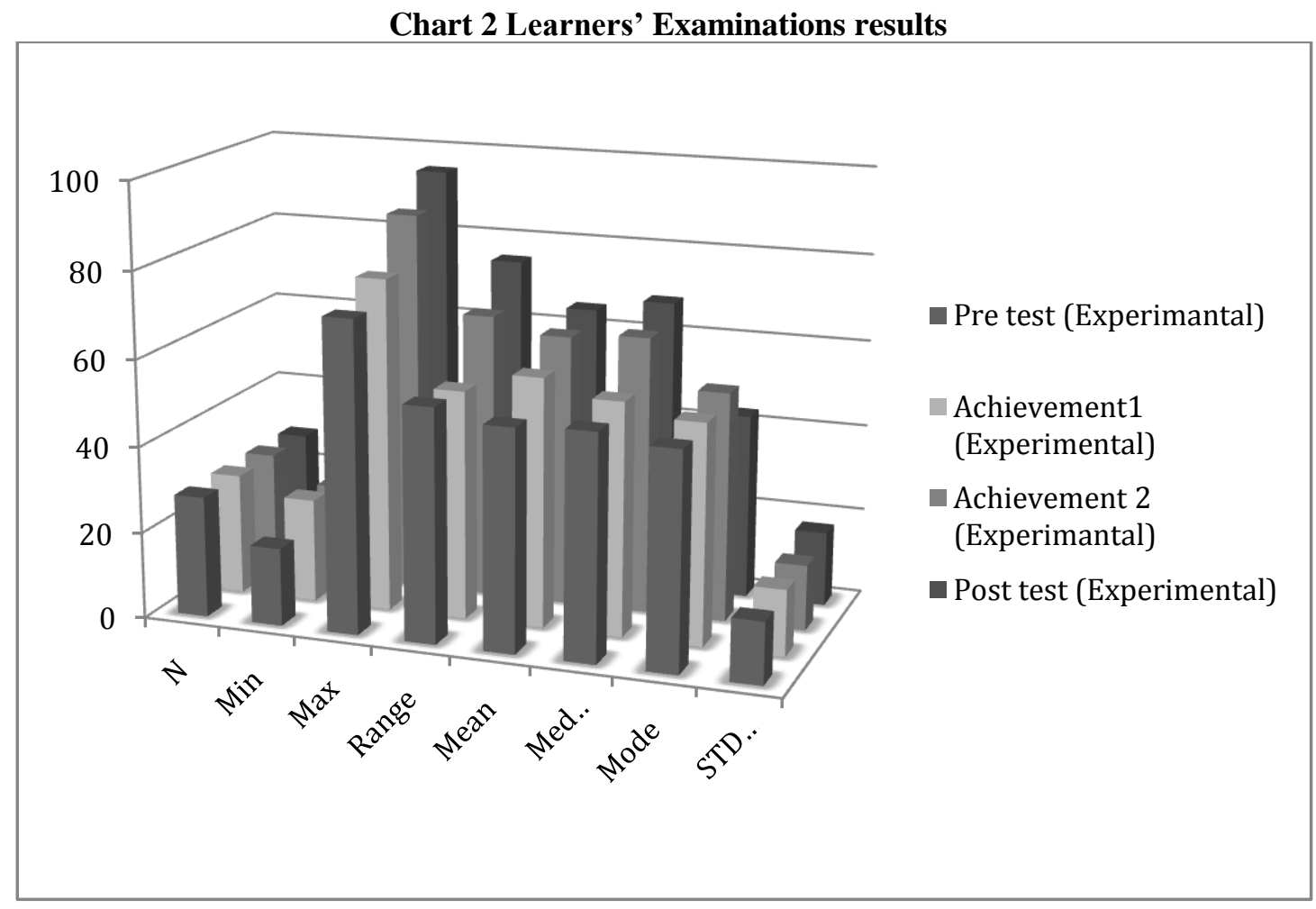

\section{Learner Interviews}

After finishing the study, the teacher had an interview with the volunteer learners in the experimental group. Nine boys and seven girls voluntarily had the interview in their native language (to avoid the language level impacting on the obtained results). The main reason for having an interview is that it allowed the teacher to speak directly to the learners, and requested their answers on the questionnaire, as well as on some other questions. By interviewing, the researcher aimed to explore whether differentiated instruction engage all the learners to create an inclusive classroom where there is always a learning atmosphere. The teacher found that the learners were very eager to participate, and consequently, that their grades improved and the classroom management problems decreased. Most of the learners interviewed expressed a liking for active participation, change, self-correction or self-reflection, which are all integrated into lessons through the use of plenty of tasks in a differentiated classroom. 


\section{Parent Interviews}

In order to measure the differences and progress, the teacher made interviews with some of the parents of the learners. She asked the parents from time to time if there has been any behavioral change in their learners' manner. Those parents told that their learners started to read, search and talk English in their daily lives. They also indicated that the learners became more eager to go to the school and did their assignments on time. One thing that the parents emphasized is that their children tried to speak, read and listen to the English in the real world like in market, bazaar or where it is needed. They started to help their friends and siblings in their English homework. The interview with the parents demonstrated that the learners could use their English in the authentic environment if they could continue to participate in the lessons.

\section{Findings}

At the end of this action research the teacher reached many positive results, which helped her to create a positive learning atmosphere by differentiating her lesson. The results that emerged with the collected data is as follows: How differentiated instruction helped the teacher to engage all the learners to create an inclusive classroom where there is always a learning atmosphere?

At the start, the teacher was suffering from different types of learners whose learning needs and interests differed markedly. The teacher found difficulties in engaging those different learners to the course and as a result classroom management problem were emerged. The teacher first engaged these learners in the lessons to identify the sources of diversity. Later on, according to those learners needs, interests, cognitive area and background information, the teacher tried to use different types of teaching methods that resulted as differentiated instructions. Learners who were interviewed told her that they all liked the ways of teaching. With the differentiated instruction, the learners had the chance to learn the same content differently. The teacher used multiple effective ways to get the same results. In her teaching, she demonstrated flexibility and surrendered the need to control what learning path the students take. What's more, she supported them in their own path, in order to achieve certain learning goals, where learners automatically had individual, tailored learning, using the gradual release of responsibility, which helped her to understand that learners are ready for independent tasks at different periods. Allowing learners to use visuals or organizers in order to have successfully completed tasks was also another way to differentiate instruction that she did. Completing a learning objective at their own reasonable pace was an important achievement for the students; by differentiating the learning process, delivery of the product became quite easy. Changing the content, process and product provided multiple entry opportunities for learners to access the same task in different ways. Being responsive to learner needs at the beginning made the learners eager to attend and participate the lessons. Consequently, the classroom became an inclusive learning environment in which all the learners joined and engaged.

\section{Will including all learners into the lesson allow learners to learn the content at a higher level?}

The teacher observed that differentiated instruction provided the opportunity for her to consider multiple characteristics of the learner simultaneously in choosing an instructional strategy for a particular learner and learning objectives. In their examinations, it can be easily seen that there was always a constant increase, and that this increasingly motivated the learners. After the learners gained experience of the fact that studying collaboratively brings the success, they became more participatory. Also, the differentiated instruction gave learners alternate paths with which to learn. Learners working below grade level were given resources that retraced major objectives already taught, whereas on the other hand, learners above grade level were asked to produce work that requires more complex and advanced thinking. By varying teaching techniques and strategies, the teacher made sure that each learner had the opportunity to learn in a manner compatible with his or her own learning strengths and preferences. This made the learners learn the content at a high cognitive level. Also, the learners demonstrated in their interviews that they identified their interests and uniqueness. They also stated that different types of content and process aroused their interests and motivation.

\section{Will creating an inclusive classroom help teachers to minimize classroom management problems?}

An inclusive classroom resulting from differentiation instruction took the form of varying the modalities, according to which learners gained access to important learning. The teacher needed to present the instruction at different levels by offering learners a choice in the complexity of content with which they would begin a learning task that matches their current level of understanding and form, which every learner could experience; academic success, presenting learners with different learning styles, such as presenting content in incremental steps, like rungs on a ladder, resulting in a continuum of skill-building task; and all learners benefitted from presenting information in a variety of ways, for example by listening, reading, and doing. As a result of such manner of participation, classroom management problems decreased. 


\section{Will creating an inclusive classroom help learners to internalize and apply the knowledge in the world around them?}

From the questionnaire and parents interview, many of the learners felt that talking English socially was a significant issue, which helped them to become more social. From the learner interviews, the teacher discovered that it was through different types of instructions that the learners were able to talk with self-esteem publicly. The classroom environment became less competitive, which helped the students to be interested in the lesson topics. From the interview, learners agreed that it was a good idea to use that English Language class content in the authentic situations and it supported to them to learn better.

\section{Discussion, Conclusion and Suggestions}

As is seen in the research findings, the inclusive classroom provided an effective learning environment in which students felt relaxed and appreciated. The curriculum and teaching methods that were used by the English Language teacher supported student inclusion and development. The study showed that a teacher changed the mood of education in her classroom where all of the learners were about to lose. It is not easy to establish an inclusive school, but we can infer from this action research that if teachers, principals and the policy makers believe and provide the needs of inclusive education, then learning and teaching would be more effective.

Since inclusive education requires more energy and more time, it introduces some financial barriers to the schools as well. However, as one of the outstanding country where the inclusive education is being enacted by the law of White Paper 6: Special Needs Education: Building an Inclusive Education and Training System(DoE, 2001), can be an example to all developing countries. They started to the inclusive education by declaring a law. The governments should support the educational institutions, although they have limited budgets, where there is a lack of official development assistance, and education is centralized. According to the UNICEF's (UNICEF, 2014)inclusive education funding report, governments can fund the inclusive education according to three models, namely the Per-Capita Model, Resource-Based model and Output-Based Model. Besides, during this action research the researcher faced many obstacles and found solutions to those challenges. For the researcher, in order to establish inclusive education financial support is not the only resources especially for KRI where the income is very low. There are some other resources apart from the financial ones:

\section{University-school collaboration}

The relationship between universities and schools can improve the quality of inclusive education. It is not possible to talk about the existence of a qualified inclusive education system unless the universities, especially Education Faculties, provide courses such as philosophy of education and special education in the curriculum and programs regarding the importance of inclusive education. These programs and curricula should be designed cooperatively by the schools and universities to meet the needs of the occupational and social requirements directly affecting the quality of the inclusive education.

\section{Pre-Service Training}

It is generally agreed upon that teachers are the key factor for implementing the inclusive education successfully. That is why teacher's knowledge, capacity, mindset and competencies can make the inclusive education work effectively. Before starting to teach, practitioners should be provided with pre-service training programs, where teachers can be trained to improve the competencies towards proficiency in teaching. This pre-service training program should include the philosophy and the policy of inclusive education. Without understanding these two concepts, teachers will always be in lack of internalizing the inclusive education. Besides, educators should be warned about the barriers of learning in inclusive classrooms. Another issue that the teacher should know during the pre-service training is that not all learners are alike, as there is always diversity among learners in schools and community.

\section{In-Service Training}

The establishment of a successful inclusive education system requires not only pre-service teacher training, but also an in-service teaching training should be conducted to promote inclusive education. It is not easy to implement inclusive education in all classrooms in a school. Therefore, teachers may confront obstacles and need a wider understanding of educational difficulties in an inclusive-learning area. Head-teachers in the workplace should hence support the professional development of other teachers in teaching philosophy, material and techniques, in accordance with the needs of an inclusive classroom. Developing teachers' competencies can give them an opportunity to adjust their teaching in line with the learners' inclusive-learning process. Thus, teachers should be developed in terms of contextual issues to provide the circumstances that promote a positive learning atmosphere for all learners. This action research shows that teachers can be persuaded to take part in in-service training programs related to inclusive education, on condition that they are actively involved in decision-making. 


\section{Peer-to-Peer Tutoring}

The action research demonstrates that children in a classroom are a main resource for researchers for disseminating the idea of inclusive education. In this peer-tutoring act, learners, especially shy ones, have shown better response to each other than to their teachers; and the educational results were even better when they managed to develop strong friendships between tutors and their tutees, which is important for including all learners in the learning and teaching process. Students also benefited each other by learning to teach spontaneously, under the researcher's observation. Ultimately, peer-tutoring gives better students the chance to strengthen their learning, and supplies weaker learners with individual support. Thus, peer-tutoring can be manipulated as a resource where there are very few opportunities.

\section{Parental Involvement}

There is a consensus amongst educationists concerning the vital role that parental involvement plays in children's education. Especially in inclusive education, which pays extra attention to students of special needs, who require special support from all stakeholders, parents should be a direct part of the education process. Cooperation between the parents and teachers has a very positive effect on child growth and development. In low-income countries, parental involvement and their training to involve them to the inclusive education can be another resource. The desired end result cannot be gained without the involvement and cooperation of families. The research shows that children make more effort at school when parents take part in their schooling.

\section{Societal Action}

This action research also shows that the involvement of families in the inclusive education leads to an inclusive education at the societal level. The researcher triggered students' families and learners in order that they involve their different local connections in the inclusive activities of school. Besides, a strong connection was established with local community leaders who provided social capital to the inclusive education. Local chiefs, elected politicians, religious and tribal leaders, and other people of influence were involved in the inclusive education after seeing its effectiveness in the researcher's model classroom and in the school on the whole. The community leaders can be invited more often to the inclusive education meetings and organizations in order to show the benefits of the program. These community leaders play a vital role in bridging the school and community resources, which they muster among the whole society Generally, teachers have suffered difficulties in their classrooms since the days of one-room schoolhouse. One way of preventing the learners' low level performance in the classroom is to be aware of the learner diversity. Teachers can adjust their expectations and adjust the content and activities according to learner differences. This is not a disservice to the learners when they are given meaningful and up to level content and develop gradually their knowledge. It is important to hold high expectations for all learners and to believe that all learners can achieve. However, the content ought also to change accordingly if the learners are wished to participate to create an inclusive environment. Learners appreciate, feel relaxed and participate more if the content is up to their level and find the classroom more stimulating and worthwhile, as compared to classroom with high-level content. Tomlinson (Tomlinson, 2001) proposes differentiation instruction as one of the solutions to overcome those obstacles and to create a positive learningatmosphere or an inclusive classroom. In order to create a true differentiation instruction, the learners' diversity should be realized in the area of their readiness, cognitive domain, interests, and learning styles. Starting with this mentality, teachers can set up an inclusive classroom where everybody works toward essential understandings and skills, but uses different content, processes, and products to get there. Differentiation is important but should not be a punitive measure by overloading the teacherIn regards to learner engagement and commitment to the courses, differentiation demands a substantial leap in the way we think about inclusion. It also gives an enthusiasm to the teachers who see themselves more as facilitators than as taskmasters.

Teachers can make decisions to ensure that the curriculum is inclusive, relevant and free of bias. Teachers can select appropriate instructional content to demonstrate that their learners are valued as people, and that they offer a challenging, culturally relevant curriculum. The content may involve integrating subject areas from diverse traditions, and the content may even arise out of learners' own questions so that they can construct their own meaning. Also, they may change the learning activity packages, for example, making groups according to their type of intelligence. Altering the length, difficulty and time span of the assignment can provide alternative and differentiated instructions. Enrichment activities also helped the teachers to create inclusive classrooms. Differentiated instruction-teaching format for covering the curriculum and for creating an inclusive environment worked in that $5^{\text {th }}$ grade classroom in English Language classroom. The teacher allowed the learners more flexibility, provided tasks and content relevant to their personal interests, and created finished products that reflect their abilities. All this resulted in increased motivation, creativity, pride in the job completed and a whole classroom engagement. 


\section{Bibliography}

Alexander, J. M., Johnson, K. E., Leibham, M. E., \& Kelley, K. (2008). The development of conceptual interests in young children. Cognitive Development, 23(2), pp. 324-334.

Allen, E. K., \& Cowdery, G. E. (2011). The exceptional child: Inclusion in early childhood education. NY: Delmar Learners.

Anderson, K. M. (2007). Differentiating instruction to include all students. Preventing School Failure, 51 (3), pp. $49-54$.

Applebee, A. N., Langer, J. A., Nystrand, M., \& Gamoran, A. (2003). Discussion-based approaches to developing understanding: Classroom instruction and student performance in middle and high school English. American Educational Research Journal, 40(3), pp. 685-730.

Bennett, H. (2001). Genres of research in multicultural education. Revieiw of Educational Research(71), pp. 171-188.

Borich, G. (2008). Characteristics of Effective Teaching. In N. Salkind, Encyclopedia of Educational Psychology (pp. 322-326). Thousand Oaks, CA: Sage Publications.

Brophy, J. (1998). Educating teachers about managing classrooms and students. Teaching and teacher Education, 4(1), pp. $1-18$.

Burden, P. R., \& Byrd, D. M. (2007). Methods for effective teaching (4 ed.). Boston, MA: Pearson.

Davies, B. (2006). Subjectification: The relevance of Butler's analysis for education. British journal of sociology of education, 27(4), pp. 425-438.

DoE. (2001). Department of Education. Retrieved 01 12, 2018, from

https://www.education.gov.za/Portals/0/Documents/Legislation/White\%20paper/Education\%20\%20White\%20Paper\% 206.pdf?ver=2008-03-05-104651-000

Engelbrecht, P., \& Oswald. M \& Forlin, C. (2006). Promoting the implementation of inclusive education in primary schools South Africa. British Journal of Special Education , 33, 121-129.

Engelbrecht, P., Nel, M., Nel, N., \& Tlale, D. (2015). Enacting understanding of inclusion in complex contexts: classroom practices of South African teachers. South African Journal of Education, 1-10.

Groundwater-Smith, S. \&. (2009). Teacher professional learning in an age of compliance: Mind the gap (Vol. 2). Springer Science \& Business Media.

Huang, H. (2002). Designing multicultural lesson plans. Multicultural Perspective, 4(4), pp. 23-31.

Nel, N., Muller, H., Hugo, A., Helldin, R., Backmann, O., Dwyer, H., \& Skarlind, A. (2011). A comparative perspective on teacher attitude-constructs that impact on inclusive education in South Africa and Sweden. South Africa Journal of Education, 31, 74-90.

Patterson, J. L., Connolly, M. C., \& Ritter, S. A. (2009). Restructuring the inclusion classroom to facilitate differentiated instruction. Middle School Journal, 41(1), pp. 46-52.

Salend, S. J. (2010). Evaluating inclusive teacher education programs: A flexible framework. Changing paradigms and innovative approaches, 130-140.

Terrell, R. D., \& Lindsey, R. B. (2008). Culturally proficient leadership: The personal journey begins within. Corwin Press.

Tomlinson, C. (2000). Differentiation of instruction in the elementary grades. ERIC Clearinghouse on Elementary and Early Childhood education.

Tomlinson, C. A. (1999). Mapping a route toward differentiated instruction. Educational Leadership, 57, pp. 12-17.

Tomlinson, C. A. (2001). How to differentiate instruction in mixed-ability classrooms. ASCD.

Tomlinson, C. A. (2003). Differentiation in Practice. Cell, 505, pp. 5450-5472.

Tomlinson, C. A. (2014). The differentiated classroom: Responding to the needs of all learners. Ascd.

UNICEF. (2014). financing of Inclusive Education. New York: UNICEF.

Walton, E., Nel, N., Hugo, A., \& Muller, H. (2009). The extent and practice of inclusion in independent schools in South Africa. South African Journal of Education, 29, 105-126.

Watts- Taffe, S., Broach, L., Marinak, B., McDonald Connor, C., \& Walker- Dalhouse, D. (2012). Differentiated instruction: Making informed teacher decisions. The Reading Teacher, 66(4), pp. 303-314.

White, B., Shimoda, T. A., \& Frederiksen, J. R. (1999). Enabling Students to Construct Theories of Collaborative Inquiry and Reflective Learning: Computer Support for Metacognitive Development. International Journal of Artificial Intelligence in Education, 10, 151-182. 